\title{
Apocalipse 1,11: \\ a redenção pelo teatro
}

\section{Silvana Garcia}

No dia 2 de outubro de 1992, no Pavilhão 9 da Casa de Detenção de São Paulo, 111 presos foram assassinados pela Tropa de Choque da Polícia Militar que invadiu o local para conter uma rebelião. O "Massacre do Carandiru", como ficou conhecido o episódio, teve repercussão mundial e até o presente não foi totalmente esclarecido.

O que vês, escreve-o num livro e manda-o às sete Igrejas... (Apocalipse, 1, 11)

\section{O Brasil da Besta}

pocalipse em grego significa revelação e é com esse sentido que o vemos empregado no Novo Testamento: revelação das verdades contidas no Evangelho e cuja realidade última é a condição de Jesus Cristo como juiz supremo da humanidade. Assim o pretendeu a tradição cristã, e o apóstolo João afirmou-se como autor do mais importante escrito apocalíptico. Foi nele que finalmente foi baseado o texto de Apocalipse 1,11, em formulação final do escritor Fernando Bonassi.

Porém, o espetáculo do Teatro da Vertigem está longe de reproduzir o universo bíblico em seu imaginário grotesco de monstrengos de muitas cabeças e estrelas que despencam dos céus. Essas aberrações e catástrofes não nos assombram, pois vivemos em um mundo no qual a ameaça de fim encontra-se neutralizada pela convivência diária com a violência, a degradação, a perda de referências. As visóes do Apocalipse não são mais feias do que a miséria que se avoluma ao nosso lado. É, pois, no plano das abominaçôes da realidade que somos atirados pelo espetáculo. E o fazemos na condição de testemunhas. Quem nos conduz em nosso trajeto é João, o apóstolo, aqui destituído de sua função profética e convertido em migrante de aparência nordestina, maleta de couro surrada na mão, olhar perdido, entre ingênuo e sofrido. Ele vem em busca de Nova Jerusalém, a terra prometida, e nós seguimos com ele.

Nossa primeira parada coloca-nos diante de um singelo ritual. A vários metros do solo, pendurada sobre uma varanda, uma menina de ar distraído bucolicamente rega um vaso de flor. Em seguida, sorriso congelado nos lábios, põelhe fogo. É um ritual que podemos entender como um batismo de água e fogo, que nos retira a inocência. Num primeiro momento não percebemos essa destituição. Nem mesmo ficamos chocados, apenas um leve mal estar.

Silvana Garcia é professora da Escola de Arte Dramática da ECA-USP e dramaturga. 
Até porque, logo em seguida, nossa atenção é capturada pela aparição, num plano ainda mais alto, da figura de um Carteiro. Ele nos lê, então, a Carta ao Anjo da Igreja em Éfeso. Porém, seu conteúdo não é o original bíblico, mas um bem humorado edito, determinando leis aparentemente absurdas como a concessão de direito a cirurgia plástica para mulheres idosas e a obrigatoriedade de pagamento de impostos para traficantes. Adivinhamos, então, que essa mistura de humor e cinismo, poesia e crueldade, estará entre os ingredientes privilegiados do espetáculo. Com esse espírito, seguimos adiante.

Penetramos, então, na privacidade de João, acompanhando-o até seu quarto, um cubículo miserável como os que podemos encontrar nas pensões vagabundas que se espalham pelos subúrbios das grandes cidades. Deslocados de testemunhas a voyeurs, espreitamos sua intimidade através de vãos de janelas e portas, obrigados pela arquitetura da sala a uma visão parcial. Às vezes, temos de contentar-nos em apenas ouvir a cena que agora se desenrola entre João e a Noi$v a$, uma jovem de aparência virginal, flagrada por ele em seu quarto. Ela se oferece a ele, disposta a submeter-se, mas João a despreza, obcecado pela idéia de Nova Jerusalém. Tão logo ela se retira, nua e desesperada, João descobre sob sua cama um outro intruso, o Senhor Morto. Sua figura é a do Cristo coroado de espinhos, decalcado na iconografia religiosa tradicional. Tampouco ele oferece a João qualquer resposta, qualquer alternativa, e também é rejeitado. Por fim, a terceira visita: o Anjo Poderoso, acompanhado por sua pequena tropa de Anjos Rebeldes. João é torturado, drogado e, por fim, recebe do Anjo a missão de sair e dar testemunho da proximidade do fim dos tempos.

Com ele seguimos em peregrinação. $\mathrm{Su}-$ bimos por escadas escuras e tortuosas, nossos ouvidos bombardeados pelo som mix de música techno e hinos religiosos, guiados por desenhos toscos de mulheres despidas, fosforescentes sob a luz negra, que nos conduzem à "Boate Nova Jerusalém”. Entramos em um salão em penumbra, chuviscado por luzes coloridas que escorrem pelo espaço. $\mathrm{O}$ ambiente remete-nos aos "inferninhos" kitsches de beira de estrada em cidadezinhas perdidas no Nordeste brasileiro. Somos dispostos em torno de uma passarela, lugar privilegiado do qual assistiremos ao grande show da noite. Quem o apresenta é a Besta, o anti-Cristo em pessoa, um exuberante travesti barbado, obsceno e provocador. Como coadjuvante, a atrevida Babilônia, que, nos intervalos das atrações e das cheiradas de cocaína, exibe despudoradamente o sexo, gabando seu talento de prostituta. Na platéia, ao nosso lado, assimilando-nos, os Adoradores da Besta, beatos devotos que assistem ao show como se a um culto religioso, dando aleluias e agitando nas mãos suas bíblias encardidas.

Aqui se concretiza a metáfora do apocalipse here and now, do apocalipse brasileiro. Nas atrações que se sucedem, vamos reconhecendo, nas personagens e nas citações, aspectos conhecidos do Brasil da violência, do preconceito, da corrupção, expostos de modo inclemente. Não há sutilezas, as referências revelam-se inequívocas. Assistimos, por exemplo, à cena da "Humilhação do Negro", no qual, introduzido como um produto nacional autêntico, alardeado em sua potência e sensualidade, um jovem negro é, em seguida, acusado de roubo e sobre ele recaem todos os clichês racistas que fazem parte da cultura classe média brasileira. Há também um número de sexo explícito, executado apaticamente por um casal em trajes indígenas, remetendo-nos inevitavelmente ao longo processo de degradação a que nossos índios encontram-se submetidos. (Os protagonistas desta cena são, de fato, profissionais de shows pornôs e a exibição efetivamente realiza-se no palco, sendo esta uma das situações que têm provocado protestos indignados de espectadores tradicionalistas).

Há ainda a exibição da Talidomida do Brasil, uma corpulenta adolescente, retardada e paralítica, presa a uma cadeira de rodas, que, com esforço, recita as primeiras linhas da Constituição Brasileira. Em seguida, ela é estuprada pela Besta e a cena se completa com a entrada festiva de um bolo, oferecido em comemoração aos 
500 anos do Descobrimento do Brasil, ao som de um alegre e comovente Parabéns a você cantado por Babilônia.

A estas cenas sucedem-se outras, de teor semelhante, fazendo desfilar na passarela situaçôes e personagens que evocam o lado podre do país. O tom é paródico, debochado, mas a linguagem é crua, obscena, blasfema. $\mathrm{O}$ jogo de tensões, o confronto entre elementos contraditórios, que constitui uma das fontes do grotesco da peça, sustentado pela alta teatralidade dos elementos em cena, retém os espectadores em uma desconfortável zona limítrofe entre o riso e o choque. Na média, nossa disposição interior manifesta-se por meios-sorrisos. Não podemos confiar plenamente naquelas personagens que, mesmo sob uma aparência infantil, podem subitamente perder o controle e praticarem atos da mais torpe violência. Este é o caso, por exemplo, dos dois palhacinhos que oferecem calças jeans, uma dupla clonada de Vladimir e Estragon cujo ponto de saturação já foi há muito ultrapassado, que já perderam a paciência e combinam ao seu pregão de vendedores os queixumes dos pessimistas e as vociferações dos revoltados. E que, em contraste com suas ternas figuras de enfeite de bolo de aniversário, espancam impiedosamente um ator vestido de coelhinho de pelúcia.

A combinação de elementos discrepantes estende-se a todos os componentes da armação dramatúrgica. Domina as falas das personagens, em geral pela justaposição da linguagem parabólica do Evangelho com palavrões e expressões da pior estirpe. Manifesta-se também na mistura do divino com o baixo material. A Besta, dedicando o show da noite a Jesus, refere-se a ele como "meu marido", como "homem da minha vida", fazendo chocantes alusōes a seu desempenho sexual.

A ambigüidade manifesta-se já, em primeira instância, na construção das próprias personagens, pois todas elas são referências míticas deformadas em seus traços arquetípicos pelas contaminações que recebem da atualidade. São, portanto, seres híbridos; contêm sempre dois pólos em tensão. Os Anjos são portadores da palavra do Evangelho, mas vestem-se e comportam-se como policiais ferozes, lembrando as tropas de choque nazistas. Suas preces combinam versos de salmos com obscenidades. Por suas bocas, também, ouvimos os slogans pelos quais se expressa o segmento mais reacionário da população, como a reivindicação da pena de morte ou a condenação indistinta de nordestinos e homossexuais. É sempre no interior desse jogo de afirmação/negação entre elementos opósitos que se constituem os sentidos das cenas.

No âmbito do conjunto, é também um jogo de contrapontos que lhe determina o ritmo e o encadeamento. Se a natureza épica do espetáculo não comporta um evolver dramático, a tensão se faz artificialmente pela teatralidade e pela aceleração/desaceleração do pulsar rítmico. Para tanto contribuem a sonoplastia e os procedimentos de montagem, com cortes e intromissōes súbitas de elementos inesperados. O desfecho do ato na boate Nova Jerusalém ilustra essa dinâmica.

\section{O Juízo Final}

Atenção capturada pelo ritmo frenético do show, demoramos a perceber, num canto da passarela, a figura apalermada de João, olhar entorpecido pela ação do crack. Assistimos a tudo como ele, com a mesma passividade bovina, e somos, como ele, surpreendidos pela entrada abrupta do Anjo poderoso e seus cães, em clima de violenta blitz policial, ameaçando as personagens que agora jazem desnudas, mãos à nuca, sobre a passarela.

Daí em diante somos carregados para um espaço de pesadelo que inevitavelmente nos remete aos porões da ditadura militar durante os piores anos da repressão. Quase no escuro, atormentados por uma sonoplastia que mistura vozes e gritos a estampidos de armas de fogo, somos introduzidos em um longo corredor e dispostos pelas paredes, ombro a ombro, formando uma espécie de "corredor polonês". Pressentimos, mais do que vemos, os corpos nus que 
passam carregados agressivamente pelos anjospoliciais. Estremecemos ao ruído de portas de aço que se fecham com estrondos, sem que situemos as fontes dos impactos. Como na História, testemunhamos, protegidos pela penumbra, assustados mas seguros, o martírio dos que são arbitrariamente submetidos à mais abominável violência.

Aqui o espaço do cárcere começa a ganhar sua plena significação. Este é o lugar que a sociedade escolheu para o confinamento daqueles que representam o desvio da norma, os transgressores, as anomalias sociais. É o lugar da exclusão, a caverna profunda que não se comunica com o exterior e que veda ao exterior a visão dos rejeitados. É o lugar da punição, da perda da liberdade, da submissão humilhante, da prevalência da força sobre a vontade. Passamos a perceber melhor a concretude material das paredes úmidas, o cheiro de pólvora que contamina levemente o ar, a topografia labiríntica de escadas e corredores que desembocam no imponente e tenebroso espaço do último ato. Estamos agora em um pátio interno de pé direito alto, cercado por dois andares de celas, as do segundo plano alinhadas junto a um corredor suspenso. Em um dos extremos, uma porta de ferro gigantesca; no outro, uma escada também de ferro, unindo os dois pavimentos. Aqui transcorrerá o Julgamento Final.

Um a um, retirados de suas celas, desfilam diante do juiz os protagonistas da devassa Nova Jerusalém. Por um breve momento, único no espetáculo, somos incitados a participar. Para o julgamento da Talidomida do Brasil, alguns ovos são distribuídos para que os espectadores, seguindo o exemplo do Juiz, atirem na personagem que, acuada e descaída, balbucia ainda a Constituição Brasileira.

A cada réu compete uma sentença e elas são executadas prontamente, sem recursos. A Noiva tem o fim das mártires virgens: a fogueira que a redime e a eleva ao Céus. Babilônia, delirante sob o efeito da cocaína, sujeita por uma camisa de força, é humilhada pelo Juiz, que urina sobre ela, e termina estrangulada pela Besta. Esta por pouco não logra seduzir o Juiz, mas acaba sendo torturada, castrada e queimada na cruz pelos Anjos. Ao final de um debate no qual se desafiam mutuamente com citações bíblicas, o Anjo Poderoso foge e o Juiz enforca-se, premido pela consciência de que não há salvação.

O epílogo restaura a harmonia. João, por fim liberado de sua obsessão, redimido, perde o medo e, depois de partilhar um cigarro com o Senhor Morto, sentados ambos displicentemente no chão do pátio, desfaz-se de seus pertences, abre a pesada porta de ferro e sai. Pela última vez o seguimos; finalmente estamos todos livres.

Se saímos aliviados, no entanto, carregamos na memória uma carga de impressões, sentimentos, percepções, entendimentos, tudo em ebulição, em choque, fazendo-nos ansiar por um momento a sós. Para refletir. Ou simplesmente respirar.

Se o que se instala em nosso espírito, a seguir, é um sentimento de indignação ou de regozijo - seja referido ao espetáculo ou à realidade que ele evoca -, no que aqui nos concerne não importa muito. Que cada um faça suas escolhas e construa seu entendimento. O que talvez seja mais interessante ressaltar é que, para alguns de nós, este espetáculo, como os anteriores da companhia, instigam-nos a pensar sobre o lugar do Teatro, sua inserção na topografia - real e simbólica - da cidade, e no lugar que nós ocupamos nele. Porque é inevitável não ler no mandamento do capítulo 1, parágrafo 11 do Apocalipse um comando que, metaforicamente, define o papel do artista e constitui, ao mesmo tempo, uma declaração de fé no poder da arte.

No final, pela mágica metamorfose operada por este espetáculo, deixamos de ser testemunhas para nos tornarmos profetas. Como João. Os portadores da revelação. Neste lugar que é o lugar da revelação, o Teatro. Que pode ser terrível e cruel, como o queria Artaud. Como este Apocalipse. 